\title{
Inclusion of Cover Crops in Cropping Sequences with Soybean Predomi- nance in the Southeast of the Humid Argentine Pampa
}

\author{
Juan P. Martínez ${ }^{1, *}$, Pablo A. Barbieri ${ }^{1,2}$, Hernán R. Sainz Rozas ${ }^{1,2}$ and Hernán E. Echeverría ${ }^{1}$ \\ ${ }^{1}$ Unidad Integrada Facultad de Ciencias Agrarias UNMP - E.E.A. INTA, Balcarce, Argentina \\ ${ }^{2}$ CONICET, Argentina
}

\begin{abstract}
The incorporation of a cover crop (CC) may be an alternative to increase soil carbon (C) and nitrogen $(\mathrm{N})$ supply in crop sequences with a high frequency of soybean. The aims of this study were (i) to determine shoot biomass production, $\mathrm{C}$ and $\mathrm{N}$ contents in the $\mathrm{CC}$ under two $\mathrm{N}$ additions, (ii) to evaluate the effect on soybean grain yield of including a $\mathrm{CC}$, and (iii) to evaluate the water productivity of the crop sequences. Crops were evaluated during three growing seasons of a long-term field trial under no tillage on Typic Argiudoll in Balcarce, Buenos Aires, Argentina. Mean CC shoot biomass was $6.6 \mathrm{Mg} \mathrm{ha}^{-1} \mathrm{yr}^{-1}$ for N-fertilized and $5.2 \mathrm{Mg} \mathrm{ha}^{-1} \mathrm{yr}^{-1}$ for non-fertilized treatments. Mean $\mathrm{C}$ and $\mathrm{N}$ accumulation in the $\mathrm{CC}$ shoot biomass were $2.8 \mathrm{Mg} \mathrm{C}$ $\mathrm{ha}^{-1} \mathrm{yr}^{-1}$ and $131 \mathrm{~kg} \mathrm{~N} \mathrm{ha}^{-1} \mathrm{yr}^{-1}$ in N-fertilized treatments, and $2.3 \mathrm{Mg} \mathrm{C} \mathrm{ha}^{-1} \mathrm{yr}^{-1}$ and $67 \mathrm{~kg} \mathrm{~N} \mathrm{ha}^{-1} \mathrm{yr}^{-1}$ in nonfertilized treatments. Soybean grain yield ranged from 2.4 to $4.3 \mathrm{Mg} \mathrm{h}^{-1}$. In two out of the three growing seasons, soybean grain yield was greater $(\mathrm{p}<0.05)$ for crop sequences that included a CC. Water productivity was higher $(\mathrm{p}<0.05)$ in crop sequences with a CC and even higher when they were $\mathrm{N}$-fertilized. The inclusion of a CC preceding soybean in crop sequences is an alternative to improve soil $\mathrm{C}$ and $\mathrm{N}$ budgets and would be a promising strategy to increase productivity and cropping system sustainability in this region.
\end{abstract}

Keywords: Yield, sustainability, carbon, nitrogen.

\section{INTRODUCTION}

The southeast of the humid Argentine Pampa is one of the regions in the world with superior conditions for grain crop production [1], due to the temperate climate, adequate rainfall and a large proportion of soils belonging to the great group Argiudolls, with high productivity. Because of this, the region has a high potential for winter and summer crop production. In recent years, soybean (Glycine $\max$ (L.) Merr.) production has increased significantly, covering over $50 \%$ of the total cultivated area of the country and recording a mean annual production of 45.3 million $\mathrm{Mg}$ over the past five years [2]. The increase in soybean production is due mainly to an increase in soybean frequency in the crop rotation. However, soybean monoculture, in particular, may have negative effects on soil quality, affecting productivity and therefore the sustainability of the system.

Soybean has adapted to different conditions, which is why it is able to keep relatively high grain yields in low fertility soils, although it has nutrient requirements similar to or higher than other crops [3]. Soybean even has the ability to take up atmospheric nitrogen $(\mathrm{N})$ through biological $\mathrm{N}$ fixation (BNF), although this process does not usually fulfill the

*Address correspondence to this author at the Unidad Integrada Facultad de Ciencias Agrarias UNMDP - E.E.A. INTA, Balcarce. CC. 276, (7620), Balcarce, Argentina; Tel: 054-02266-43-9100; Fax:054-02266-43-9101;

E-mail: juanpablomartinez999@hotmail.com crop $\mathrm{N}$ requirements, resulting in a negative balance of this nutrient in the soil [4]. A review by Salvagiotti et al. [5] reported that BNF only contributes between $50 \%$ and $60 \%$ of the soybean crop demand. However, if $\mathrm{N}$ contribution of the roots is considered, soil $\mathrm{N}$ balance could become neutral or just slightly negative [5]. According to estimates by Collino et al. [6] made in the southeast of Buenos Aires Province, BNF contributed about $44 \%$ of the total $\mathrm{N}$ demand for the soybean crop. Despite this, generally soybean did not have greater yield due to $\mathrm{N}$ fertilization [7], and this is related to decreases in the contribution of $\mathrm{N}$ by BNF [5]. Therefore, $\mathrm{N}$ fertilization of soybean would not be the best alternative to improve soil $\mathrm{N}$ balance.

Another negative feature of the increase of soybean frequency in the rotation is the low quantity of crop residues returned to the soil. In addition, the soybean residues have a low carbon:nitrogen ratio $(\mathrm{C}: \mathrm{N})$ resulting in rapid decomposition rates. These crop characteristics can lead to decreases in the soil organic carbon (SOC) [8]. SOC is considered a key component of the soil, directly or indirectly affecting many of the parameters that define its quality $[9,10]$. Sainz Rozas et al. [11] identified significant reductions in SOC due to agricultural intensification, particularly in the north and west of the Argentine Pampa. In the southeast of Buenos Aires Province, the decrease in SOC was lower but also relevant, showing SOC content 36\% lower than pristine soil conditions [11]. Therefore, it is important to identify management practices that tend to improve the $\mathrm{C}$ and $\mathrm{N}$ balance in crop sequences with a predominance of soybean, in order 
to maintain soil quality and the sustainability of the system. The integration of practices that promotes a positive $\mathrm{C}$ balance, such as no-tillage (NT), crop rotation, fertilization, inclusion of cover crops, and proper management of available water would maintain or increase the SOC level [10].

An alternative to increase the amount of biomass returned to the soil is through the sustainable intensification of agriculture. Indeed, the intensification sequence index (ISI) is an intuitive indicator that expresses the number of crops per year in a given crop sequence, which is associated with a more efficient capture of resources $[12,13]$. In a study carried out by Caviglia et al. [14] in southern Buenos Aires Province, it was determined that wheat (Triticum aestivum L.)/soybean sequential double crops increased water and radiation productivity compared to sole crops due to an improvement in the capture of these resources. The inclusion of cover crops (CCs) during the winter season could be one strategy to increase the ISI in crop sequences where soybean predominates. The CCs provide additional biomass, increasing the amount of $\mathrm{C}$ that is put into the soil, which can improve its quality due to the positive effect on its physical, chemical and biological properties [15, 16]. Accordingly, Villamil et al. [17] and Blanco-Canqui et al. [18] reported that the inclusion of a $\mathrm{CC}$ increased SOC and this was related to improvements in the soil's physical properties.

Grass CCs generally increase $\mathrm{C}$ and $\mathrm{N}$ accumulation in response to $\mathrm{N}$ fertilization [19]. In addition, $\mathrm{N}$ uptake by grass $\mathrm{CCs}$ decreases the risk of $\mathrm{NO}_{3}$-leaching in fallow periods $[20,21]$. As a consequence, CCs could increase N capture with no direct effects on the BNF [22]. Sainju et al. [23] reported that the inclusion of $\mathrm{CCs}$ increased SOC and soil organic $\mathrm{N}(\mathrm{SON})$, improving the productivity of the soil.

Although it is accepted that CCs have the potential to improve soil quality, contradictory information exists about the effect on the yield of subsequent crops. Several authors reported that the inclusion of CCs in a cropping sequence did not reduce soybean grain yield when water did not limit crop production [19, 20]. However, Singer and Kohler [24], and Westgate et al. [25], reported reductions in soybean yield and shoot biomass accumulation, utilizing rye (Secale cereale $\mathrm{L}$.) as the $\mathrm{CC}$ in their studies in Iowa. On the other hand, Nielsen et al., [26] in a semi-arid condition, determined reduction in wheat (Triticum aestivum L.) yield seeded following a legumes $\mathrm{CC}$, due to a decrease in water availability.

In general, there is little information in the current research literature on the introduction of a $\mathrm{CC}$ with or without $\mathrm{N}$ fertilization in systems with a predominance of soybean as an alternative to increase the balance of $\mathrm{C}$ and $\mathrm{N}$, and of the effect of this management practice on the productivity of the system. In southern Buenos Aires Province, due to the increase in the cultivation of soybean in crop rotation and the current state of degradation of the soil, this information would be extremely useful. This study evaluates the importance of $\mathrm{CC}$ on biomass production, $\mathrm{C}$ and $\mathrm{N}$ accumulation, and soybean grain yield. This information is useful in order to define strategies to improve or at least attenuate soil degradation, in cropping sequences with high soybean frequency, and in this way increasing the sustainability of the production system.
The aims of this study after three years of implementating different cropping sequences with a predominance of soybean in a Typic Argiudoll in Balcarce were (i) to determine shoot biomass production, $\mathrm{C}$ and $\mathrm{N}$ contents in the $\mathrm{CC}$ under two $\mathrm{N}$ rates, (ii) to evaluate the effect of including a $\mathrm{CC}$ on soybean grain yield and (iii) to evaluate the water productivity of the crop sequences.

\section{MATERIALS AND METHODOLOGY}

A long-term field trial under no-tillage was started in 2006 at the Unidad Integrada Balcarce, in Balcarce, Buenos Aires Province, Argentina (37 $45^{\prime} \mathrm{S}$ and $58^{\circ} 18^{\prime} \mathrm{W} ; 870 \mathrm{~mm}$ mean annual rainfall; $13.8^{\circ} \mathrm{C}$ mean temperature; $138 \mathrm{~m}$ above sea level). The soil found at the experimental site is a Typic Argiudoll with less than a $2 \%$ slope. The soil has a loam texture at the surface layer $(0-20 \mathrm{~cm}$ depth), with an average particlesize distribution of $23 \%$ clay, $36 \%$ silt and $41 \%$ sand. The subsurface layer $(25-110 \mathrm{~cm}$ depth) has clay-loam texture. Prior to the establishment of the experiment, the site had been under conventional tillage for more than 25 years. Tillage comprised moldboard plowing (from $10 \mathrm{~cm}$ to $15 \mathrm{~cm}$ deep), disking and field cultivation with the least tillage operations necessary to get an appropriate seedbed. In 2006, at the beginning of the study, soil $\mathrm{pH}$ in the $0-20 \mathrm{~cm}$ depth was 5.4, and SOC and P-Bray were $26.7 \mathrm{~g} \mathrm{C} \mathrm{kg}^{-1}$ and $14 \mathrm{mg} \mathrm{P} \mathrm{kg}^{-1}$, respectively [Barbieri, personal communication].

The experimental design consisted of a randomized completely blocks design (RCBD) with three replications per treatment. Three treatments were evaluated: soybean monoculture ( $\mathrm{Sb})$; cover crop/soybean $(\mathrm{CC} / \mathrm{Sb})$ and $\mathrm{N}$ fertilized cover crop/soybean $\left(\mathrm{CC}_{\mathrm{F}} / \mathrm{Sb}\right)$. The experimental units were $15 \mathrm{~m} \times 5 \mathrm{~m}$ plots. The $\mathrm{CC}$ was oats (Avena sativa L.), which was chosen because it is a grass with a high growth rate spring-winter. It was sown with seed density of $120 \mathrm{~kg} \mathrm{ha}^{-1}$ and $0.175 \mathrm{~m}$ row spacing. In the $\mathrm{N}$-fertilized CC treatment, the dose was $90 \mathrm{~kg} \mathrm{~N} \mathrm{ha}^{-1}$ broadcast at tillering, corresponding to decimal state Z23 [27]. Cover crops were killed at flag leaf just visible, corresponding to state Z37 [27], with 3-4 $\mathrm{L} \mathrm{ha}^{-1}$ of glyphosate (48\% active principle). Treatment $\mathrm{Sb}$ was maintained without weeds during the fallow period using an application of glyphosate at the beginning of spring. Soybean was sown in rows spaced $0.35 \mathrm{~m}$ apart and with a density of 450,000 seeds $\mathrm{ha}^{-1}$ inoculated with Bradyrhizobium japonicum. At sowing, it was fertilized with $20 \mathrm{~kg} \mathrm{P} \mathrm{ha}{ }^{-1}$ as triple superphosphate (0-46-0) and 15 $\mathrm{kg} \mathrm{S} \mathrm{ha}{ }^{-1}$ as gypsum $\left(\mathrm{SO}_{4} \mathrm{Ca} 2 \mathrm{H}_{2} \mathrm{O}, 16 \% \mathrm{~S}, 20 \% \mathrm{Ca}\right)$. Pests, weeds and diseases were controlled with chemical methods. Crop sequences were assessed three years after beginning the trial, in growing seasons 2009/10, 2010/11 and 2011/12. More information about crop management and total rainfall during crop growing seasons are shown in Table 1. Decadic rainfall and temperate data were obtained from INTA's weather station, situated $500 \mathrm{~m}$ from the experimental site (Fig. 1 and 2).

Immediately before applying glyphosate to $\mathrm{CCs}$, above-ground biomass was harvested from three $0.35 \mathrm{~m} 2$ sub-samples per plot. For this, shoot biomass was clipped just above the surface of the soil. The samples were dried at $60^{\circ} \mathrm{C}$ in an oven until a constant weight was achieved (this took approximately a week). Similar methodology was utilized in 2010/11 and 2011/12 at soybean final grain filling, 
Table 1. Management data for crops and total rainfall during the growing period of cover crops and soybean in the growing seasons 2009/10, 2010/11 and 2011/12 in Balcarce, Argentina

\begin{tabular}{|c|c|c|c|}
\hline & 2009/10 & 2010/11 & Cover crop (oats) \\
\hline \hline & \multicolumn{3}{|c|}{ 2011/12 } \\
\hline Sowing date & $22 / 05 / 2009$ & $14 / 05 / 2010$ & $01 / 06 / 2011$ \\
\hline Killing date & $21 / 10 / 2009$ & $18 / 10 / 2010$ & 276 \\
\hline Total rainfall (mm) & 347 & 334 & $24 / 11 / 2011$ \\
\hline Sowing date & & Soybean & DM 3810 \\
\hline Variety & $13 / 11 / 2009$ & $20 / 11 / 2010$ & $13 / 4 / 2012$ \\
\hline Harvest date & Nidera 4209 & DM 4970 & 457 \\
\hline Total rainfall $(\mathrm{mm})$ & $10 / 4 / 2010$ & $27 / 4 / 2011$ & 433 \\
\hline
\end{tabular}

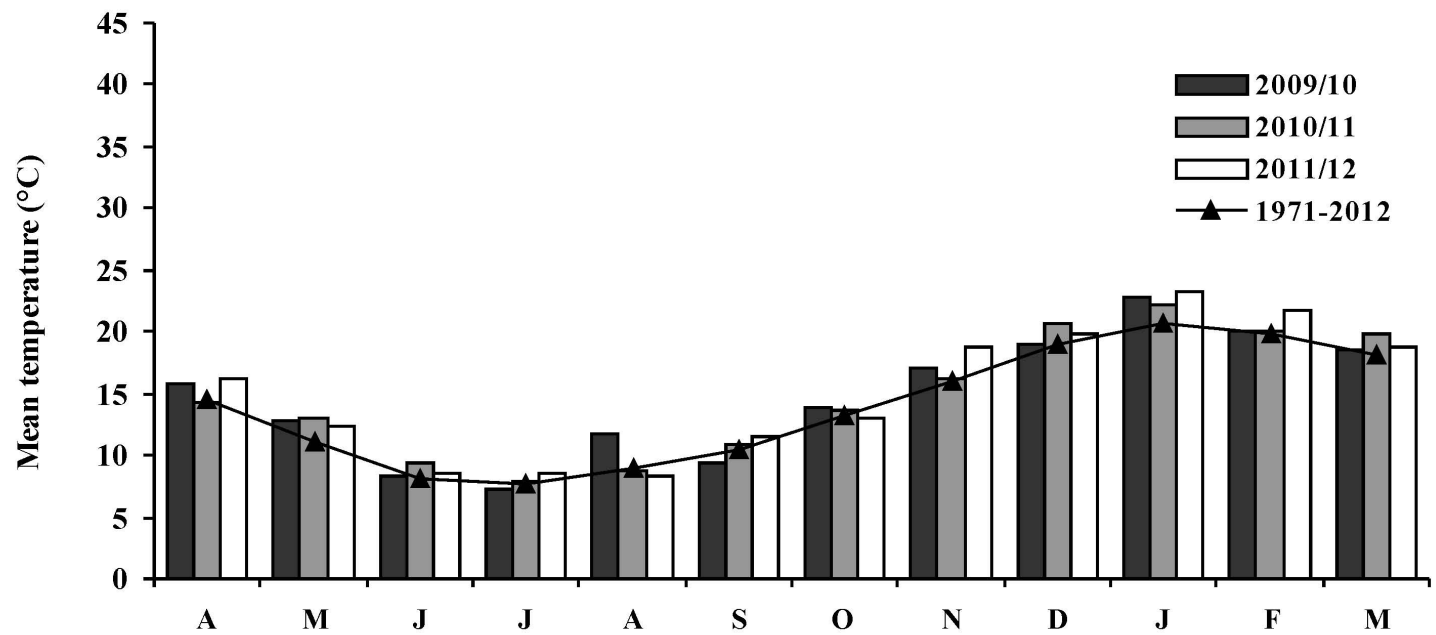

Fig. (1). Average monthly temperature in 2009/10, 2010/11 and 2011/12 growing seasons and historical average monthly temperature 19712012 in Balcarce, Argentina.

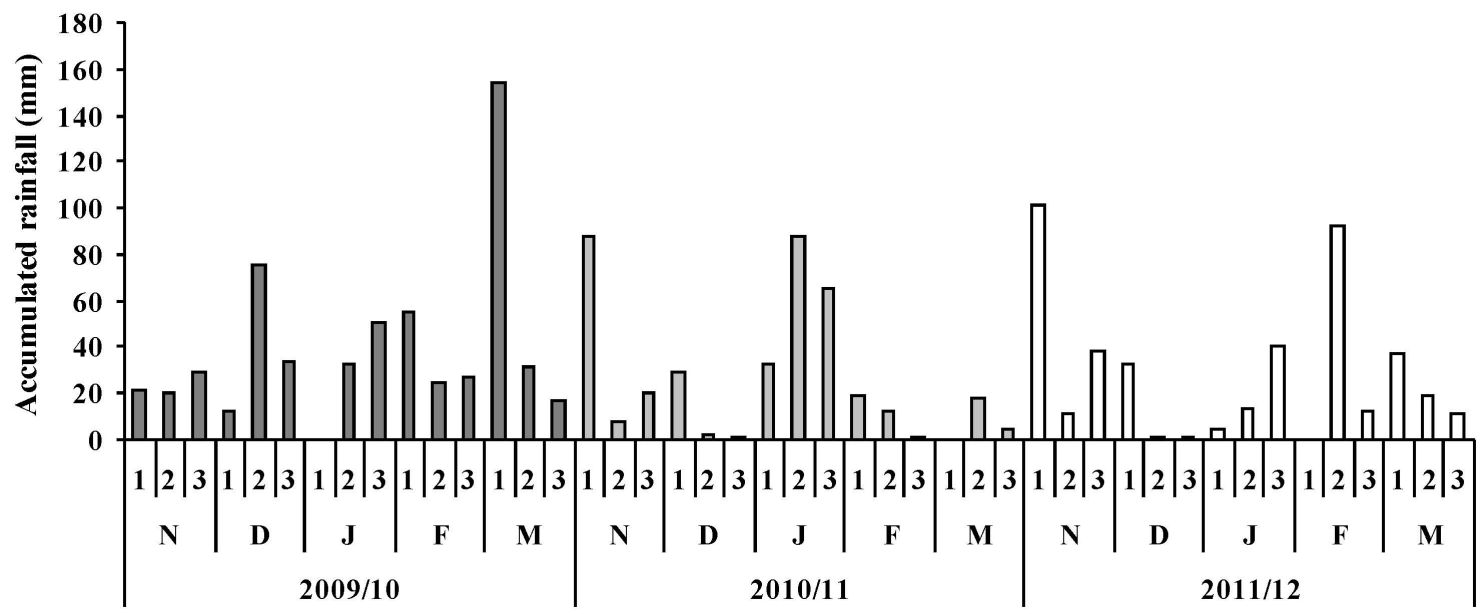

Fig. (2). Decadic rainfall in 2009/10, 2010/11 and 2011/12 soybean growing seasons in Balcarce, Argentina.

corresponding to R6 stage [28], to determine soybean shoot biomass. Dry samples of CC shoot biomass were ground (1 $\mathrm{mm}$ ) to determine $\mathrm{C}$ and $\mathrm{N}$ concentration using the Dumas method of dry combustion at $950^{\circ} \mathrm{C}$ and $\mathrm{CN}$ thermoconductivity detection using a TruSpec CN analyzer [29]. At soybean maturity, defined as R8 [28], harvest was carried 
Table 2. Nitrogen ( $N$ ) and Carbon (C) concentration, $C: N$ ratio, Shoot Biomass Production and $N$ and $C$ content of the cover crops in the growing seasons 2009/10, 2010/11 and 2011/12 in the cropping sequences: cover crop/soybean (CC/Sb); N-fertilized cover crop/soybean $\left(\mathrm{CC}_{\mathrm{F}} / \mathrm{Sb}\right)$ in Balcarce, Argentina. When interaction cropping sequence (CS) $\mathrm{x}$ growing season (GS) was significant $(p<0.05)$ simple effects were evaluated. The main effect was evaluated when interaction GS $x$ CS was not significant. Means were compared using the LSD test. different lower case letters indicate significant $(p<0.05)$ differences between CS. Different capital letters indicate significant $(p<0.05)$ differences between GS. Values in parenthesis indicate standard error of the Mean

\begin{tabular}{|c|c|c|c|c|c|c|}
\hline Treatments & $\begin{array}{c}\mathrm{N} \\
\left(\mathrm{g} \mathrm{kg}^{-1}\right)\end{array}$ & $\begin{array}{c}\mathrm{C} \\
\left(\mathrm{g} \mathrm{kg}^{-1}\right)\end{array}$ & $C: N$ & $\begin{array}{c}\text { Shoot Biomass } \\
\left(\mathrm{Mg} \mathrm{ha}^{-1}\right)\end{array}$ & $\begin{array}{c}\mathrm{C} \\
\left(\mathrm{Mg} \mathrm{ha}^{-1}\right)\end{array}$ & $\begin{array}{c}\mathrm{N} \\
\left(\mathrm{kg} \mathrm{ha}^{-1}\right)\end{array}$ \\
\hline & \multicolumn{6}{|c|}{$2009 / 10$} \\
\hline $\mathrm{CC} / \mathrm{Sb}$ & $15.7(0.1) \mathrm{b} \mathrm{A}$ & $440(1.7)$ & $28(0.3)$ a C & $4.0(0.3)$ & $1.8(0.1)$ & $63(3.8) \mathrm{b} \mathrm{A}$ \\
\hline \multirow[t]{2}{*}{$\mathrm{CC}_{\mathrm{F}} / \mathrm{Sb}$} & $21.0(1.0)$ a A & $430(4.1)$ & $21(1.1) \mathrm{b} \mathrm{A}$ & $5.0(0.2)$ & $2.2(0.1)$ & $104(2.0) \mathrm{a} \mathrm{C}$ \\
\hline & \multicolumn{6}{|c|}{$2010 / 11$} \\
\hline $\mathrm{CC} / \mathrm{Sb}$ & $9.9(0.5) b \mathrm{C}$ & $430(0.6)$ & $44(2.4)$ a A & $6.6(0.6)$ & $2.8(0.3)$ & $65(5.8) \mathrm{b} \mathrm{A}$ \\
\hline \multirow[t]{2}{*}{$\mathrm{CC}_{\mathrm{F}} / \mathrm{Sb}$} & $18.9(1.2)$ a B & $428(1.5)$ & $23(1.4) \mathrm{b} \mathrm{A}$ & $8.4(0.5)$ & $3.6(0.2)$ & $158(4.3)$ a A \\
\hline & \multicolumn{6}{|c|}{$2011 / 12$} \\
\hline $\mathrm{CC} / \mathrm{Sb}$ & $14.3(0.3) \mathrm{b} B$ & $436(0.9)$ & $30(0.6)$ a B & $5.1(0.4)$ & $2.2(0.2)$ & $73(7.1) \mathrm{b} \mathrm{A}$ \\
\hline \multirow[t]{2}{*}{$\mathrm{CC}_{\mathrm{F}} / \mathrm{Sb}$} & $20.5(0.6)$ a $\mathrm{A}$ & $435(2.2)$ & $21(0.6) \mathrm{b} \mathrm{A}$ & $6.4(0.1)$ & $2.8(0.0)$ & $130(2.4)$ a B \\
\hline & \multicolumn{6}{|c|}{ Mean CS } \\
\hline $\mathrm{CC} / \mathrm{Sb}$ & $13.3(0.9)$ & $435(1.6) \mathrm{a}$ & $34(2.5)$ & $5.2(0.4) \mathrm{b}$ & $2.3(0.2) \mathrm{a}$ & $67(3.2)$ \\
\hline \multirow[t]{2}{*}{$\mathrm{CC}_{\mathrm{F}} / \mathrm{Sb}$} & $20.1(0.6)$ & $431(1.8) \mathrm{a}$ & $22(0.6)$ & $6.6(0.5) \mathrm{a}$ & $2.8(0.2) \mathrm{a}$ & $131(7.8)$ \\
\hline & \multicolumn{6}{|c|}{ Mean GS } \\
\hline $2009 / 10$ & $18.3(1.3)$ & 435 (2.9) A & $24(1.8)$ & $4.5(0.3) \mathrm{C}$ & $2.0(0.1) \mathrm{C}$ & $84(9.4)$ \\
\hline $2010 / 11$ & $14.4(2.1)$ & $429(0.8) \mathrm{A}$ & $33(4.8)$ & $7.5(0.5) \mathrm{A}$ & $3.2(0.2) \mathrm{A}$ & $111(21.0)$ \\
\hline \multirow[t]{2}{*}{$2011 / 12$} & $17.4(1.4)$ & $436(1.1) \mathrm{A}$ & $26(2.1)$ & $5.7(0.3) \mathrm{B}$ & $2.5(0.1) \mathrm{B}$ & $101(13.3)$ \\
\hline & \multicolumn{6}{|c|}{$\mathrm{p}<$} \\
\hline $\mathrm{CS}$ & 0.006 & 0.093 & $<0.001$ & 0.047 & 0.054 & 0.005 \\
\hline GS & $<0.001$ & 0.070 & $<0.001$ & $<0.001$ & $<0.001$ & $<0.001$ \\
\hline $\mathrm{GS} \times \mathrm{CS}$ & $<0.001$ & 0.144 & $<0.001$ & 0.315 & 0.258 & $<0.001$ \\
\hline
\end{tabular}

out by plot combine and grain yield was determined by harvesting a surface of $1.05 \mathrm{~m}$ wide and $10 \mathrm{~m}$ long $\left(10.5 \mathrm{~m}^{2}\right)$ per plot. The moisture of grain samples was measured and soybean yield was corrected to grain moisture $13.5 \%$.

Water productivity (WP) was calculated as the ratio between total accumulated shoot biomass for each sequence $\left(\mathrm{Sb}, \mathrm{CC} / \mathrm{Sb}\right.$ and $\mathrm{CC}_{\mathrm{F}} / \mathrm{Sb}$ ) and the total accumulated rainfall in the three growing seasons. In growing season 2009/10, soybean shoot biomass was not determined, so this was estimated as the ratio between soybean grain yield and of harvest index. For this, a value of harvest index of 0.4 was used [8]. ISI was calculated as the ratio between the number of crops in each crop sequence and the length of the sequence [13].

Homogeneity of variance and normality tests were performed for each analyzed variable. $\mathrm{C}$ and $\mathrm{N}$ concentrations, $\mathrm{C}: \mathrm{N}$ ratio, shoot biomass, $\mathrm{C}$ and $\mathrm{N}$ content of the $\mathrm{CC}$ and soybean grain yield were analyzed through a repeated measure model. This model was used to incorporate the correlations for the errors arising from measurements on the same experimental unit through the years. These analyses were done using the MIXED procedure and REPEATED option of the Statistical Analysis System (SAS) [30]. When the interaction cropping sequences $\mathrm{x}$ growing season was significant $(p<0.05)$, simple effects were evaluated. The main effect was evaluated when interaction cropping sequence $\mathrm{x}$ growing season was not significant. Total accumulated shoot biomass and WP was analyzed using the MIXED procedure of SAS, which treated cropping sequence as fixed effect and block as random effect. When F statistic was significant, Least Significant Difference (LSD) at the 0.05 level was used to separate the means among treatments.

\section{RESULTS AND DISCUSSION}

\section{Shoot Biomass, $\mathrm{C}$ and $\mathrm{N}$ Contents in $\mathrm{CC}$}

In the growing season $2009 / 10$ and $2010 / 11$, the total rainfall during the CC's growing period was close to the historical median of $337 \mathrm{~mm}$ (Table 1), while in 2011/12 it was $61 \mathrm{~mm}$ lower. Shoot biomass production, C concentration and $\mathrm{C}$ content of $\mathrm{CC}$ were not affected by a significant $(p<0.05)$ interaction year and cropping sequences, and ranged between $4 \mathrm{Mg} \mathrm{ha}^{-1}$ and $8.4 \mathrm{Mg} \mathrm{ha}^{-1}$ (Table 2). This is in line with the report by Restovich et al. [20], who used oats as the $\mathrm{CC}$ in the northern region of the Argentine Pampa 


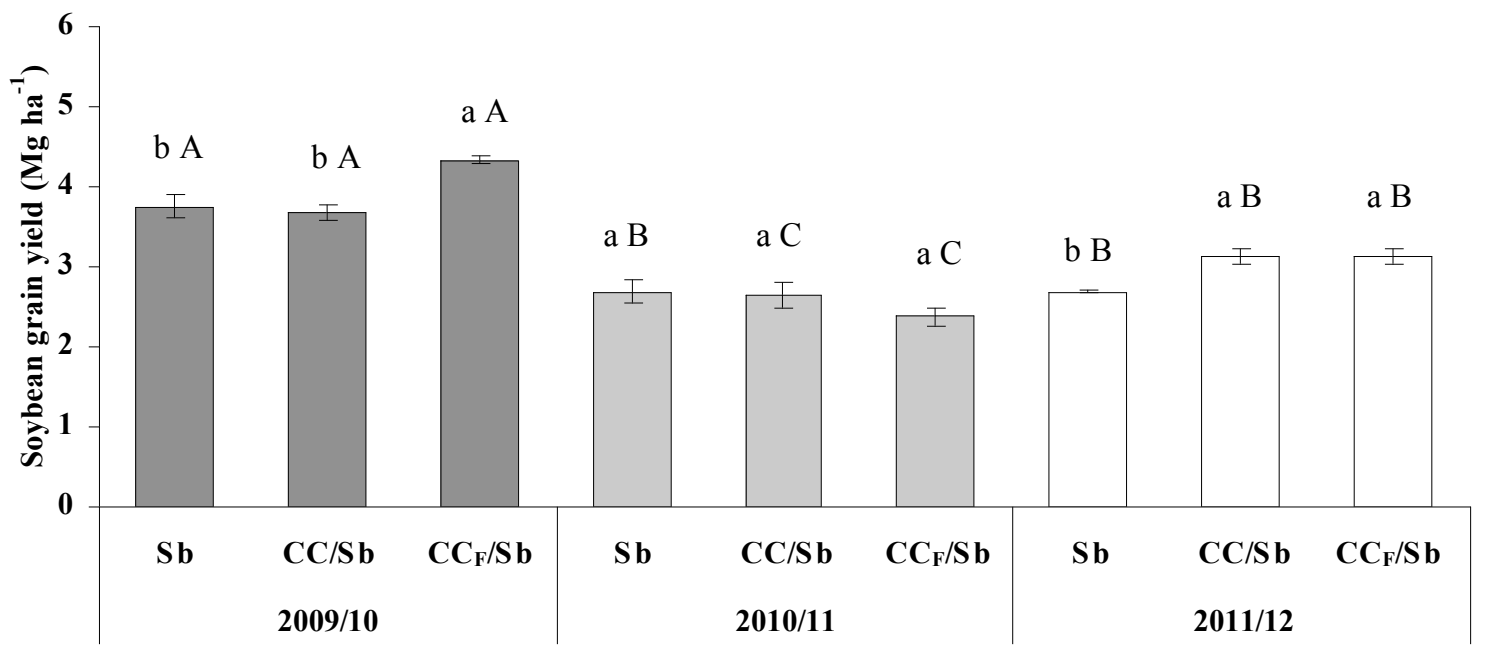

Fig. (3). Soybean grain yield $\left(\mathrm{Mg} \mathrm{ha}^{-1}\right)$ in the growing season 2009/10, 2010/11 and 2011/12 in the cropping sequences: soybean monoculture ( $\mathrm{Sb}$ ); cover crop/soybean $(\mathrm{CC} / \mathrm{Sb})$; $\mathrm{N}$-fertilized cover crop/soybean $\left(\mathrm{CC}_{\mathrm{F}} / \mathrm{Sb}\right)$ in Balcarce, Argentina. Vertical bars for each column indicate standard error of the mean. Means were compared using the LSD test. Different lower case letters indicate significant ( $<<0.05)$ differences between cropping sequences. Different capital letters indicate significant $(\mathrm{p}<0.05)$ differences between growing seasons.

without $\mathrm{N}$ fertilization. In addition, these values were in the range reported by other studies using grasses as the $\mathrm{CC}[31$, 19]. In 2010/11, the CC shoot biomass was higher $(\mathrm{p}<0.05)$ than in the other growing seasons (Table 2). This could be attributed to different causes, such as the earlier sowing date in 2010/11, which gave a longer CC growing period compared to other years, the lowest accumulated rainfall in the cycle 2011/12, and the lower temperatures in late winter and early spring (September) in 2009/10 (Table 1 and Fig. 1). The average shoot biomass production in the three growing seasons was $6.6 \mathrm{Mg} \mathrm{ha}^{-1} \mathrm{yr}^{-1}$ in $\mathrm{CC}_{\mathrm{F}} / \mathrm{Sb}$ and $5.2 \mathrm{Mg} \mathrm{ha}^{-1} \mathrm{yr}^{-1}$ in $\mathrm{CC} / \mathrm{Sb}$. This represents $2.8 \mathrm{Mg} \mathrm{C} \mathrm{ha}^{-1} \mathrm{yr}^{-1}$ and $2.3 \mathrm{Mg} \mathrm{C}$ $\mathrm{ha}^{-1} \mathrm{yr}^{-1}$, respectively. Shoot biomass was greater $(\mathrm{p}<0.05)$ in $\mathrm{CC}_{\mathrm{F}} / \mathrm{Sb}$ (Table 2). Similar results were reported by Ruffo et al. [19] in Illinois. They determined a higher shoot biomass production of rye $\mathrm{CC}$ when $\mathrm{N}$ availability increased due to $\mathrm{N}$ fertilizers applied to the previous corn (Zea mays L.) crop.

Beyond the differences among treatments with or without $\mathrm{N}$ fertilization, $\mathrm{CC}$ produced high amounts of biomass in the winter period. This may increase the amount of residues in the soil compared to soybean monoculture. It could, therefore, have a beneficial effect on the soil, diminishing the risk of erosion and soil surface crusting [32], during the $\mathrm{CC}$ and soybean growing season. Furthermore, a greater amount of residues on the surface may improve water conservation due to an increase in infiltration and reduced evaporation, mainly in the spring and summer seasons $[15,33]$. The additional $\mathrm{C}$ input to the soil by $\mathrm{CC}$ improves the $\mathrm{C}$ balance in cropping sequences with soybean predominance. Therefore, it could be beneficial for productivity and sustainability of the cropping system [10].

Shoot biomass $\mathrm{N}$ concentration, $\mathrm{C}: \mathrm{N}$ ratio and $\mathrm{N}$ content of the CC were affected by significant $(\mathrm{p}<0.05)$ interaction growing season $x$ cropping sequence (Table 2). In 2010/11, $\mathrm{N}$ concentration was lower $(\mathrm{p}<0.05)$ than in other growing seasons. An explanation for this would be an $\mathrm{N}$ dilution effect due to a great shoot biomass accumulation in this grow- ing season. This dilution effect was more evident in $\mathrm{CC} / \mathrm{Sb}$ due to no $\mathrm{N}$ fertilization. Therefore, $\mathrm{CC} / \mathrm{Sb}$ registered the higher $(\mathrm{p}<0.05) \mathrm{C}: \mathrm{N}$ ratio in $2010 / 11$, while in $\mathrm{CC}_{\mathrm{F}} / \mathrm{Sb}$ it was not significantly different $(\mathrm{p}<0.05)$ across years. In the three growing seasons, $\mathrm{N}$ concentration and $\mathrm{N}$ content in $\mathrm{CC}$ shoot biomass was higher $(\mathrm{p}<0.05)$ in the $\mathrm{N}$ fertilized treatment. As a consequence, the $\mathrm{C}: \mathrm{N}$ ratio was lower $(\mathrm{p}<0.05)$ compared to treatment without $\mathrm{N}$ fertilization. This is in line with the report by Ruffo et al. [19], which determined higher $\mathrm{N}$ concentration and a lower $\mathrm{C}: \mathrm{N}$ ratio in rye when there was an increase in $\mathrm{N}$ availability. The low $\mathrm{C}: \mathrm{N}$ ratio is associated with an increase of $\mathrm{N}$ release via mineralization [34, 35], which may be available in the soil for subsequent crops. On average, for the three growing seasons, $\mathrm{N}$-fertilized $\mathrm{CC}$ accumulated $131 \mathrm{~kg} \mathrm{~N} \mathrm{ha}^{-1} \mathrm{yr}^{-1}$ in shoot biomass, while nonfertilized CC accumulated $67 \mathrm{~kg} \mathrm{~N}^{-1}$. The literature shows similar CC N content in grasses, and this depends on $\mathrm{N}$ availability in the soil and shoot biomass production [19, 21, 31]. Although the sequence $\mathrm{CC} / \mathrm{Sb}$ showed the lowest $(\mathrm{p}<0.05) \mathrm{N}$ accumulation in every cycle (Table 2), due to the lowest shoot biomass production and the lowest $\mathrm{N}$ concentration, the amount of $\mathrm{N}$ accumulated can be regarded as important because it is derived from the soil and not from the fertilizer. Therefore, $\mathrm{N}$ content in $\mathrm{CC} / \mathrm{Sb}$ indicates a beneficial effect of $\mathrm{CC}$ due to the reduced risk of $\mathrm{N}$ leaching [19-21].

In addition, the $\mathrm{N}$ immobilized by the $\mathrm{CC}$ may later be mineralized in the soil and absorbed by subsequent crops in the rotation [33]. Is important to consider that the reported values of $\mathrm{C}$ and $\mathrm{N}$ accumulation in $\mathrm{CC}$ were determined only in shoot biomass, so if the root biomass and root exudates are included [36], these values would be increased and the beneficial effect of the $\mathrm{CC}$ on $\mathrm{C}$ and $\mathrm{N}$ accumulation would be higher.

\section{Soybean Grain Yield}

Soybean grain yield ranged from 2.4 to $4.3 \mathrm{Mg} \mathrm{ha}^{-1}$ (Fig. 3), similar to what was reported in other regional studies under non-irrigated field conditions in which water availabil- 
Table 3. Total Accumulated shoot biomass (soybean + cover crop) in the growing season 2009/10, 2010/11 and 2011/12, and water productivity (WP) in the cropping sequences: soybean monoculture (Sb); cover crop/soybean (CC/Sb); N-fertilized cover crop/soybean $\left(\mathrm{CC}_{\mathrm{F}} / \mathrm{Sb}\right)$ in balcarce, argentina. WP was calculated as a ratio between total accumulated shoot biomass and total accumulated rainfall in the Three Growing Seasons $(2,503 \mathrm{~mm})$. different letters indicate significant $(\mathbf{p}<0.05)$ differences between cropping sequences using the LSD test. Values in parenthesis indicate standard error of the mean

\begin{tabular}{|c|c|c|}
\hline Cropping Sequence & $\begin{array}{c}\text { Total Shoot Biomass } \\
\left(\mathbf{M g ~ h a} \mathbf{~}^{-1}\right)\end{array}$ & $\begin{array}{c}\text { WP } \\
\left(\mathbf{k g ~ h a}^{-1} \mathbf{m m}^{-\mathbf{1}}\right)\end{array}$ \\
\hline \hline $\mathrm{Sb}$ & $22.5(0.57) \mathrm{c}$ & $9.0(0.23) \mathrm{c}$ \\
\hline $\mathrm{CC} / \mathrm{Sb}$ & $39.1(1.88) \mathrm{b}$ & $15.6(0.75) \mathrm{b}$ \\
\hline $\mathrm{C} \mathrm{F}_{\mathrm{F}} / \mathrm{Sb}$ & $44.6(0.33) \mathrm{a}$ & $17.8(0.13) \mathrm{a}$ \\
\hline $\mathrm{p}$ & $<0.001$ & $<0.001$ \\
\hline
\end{tabular}

ity is the major determinant [37]. For the three growing seasons, the average grain yield was $3.0 \mathrm{Mg} \mathrm{ha}^{-1}$ in the monoculture, and 3.3 $\mathrm{Mg} \mathrm{ha}^{-1}$ and 3.2 $\mathrm{Mg} \mathrm{ha}^{-1}$ when it was sown after a $\mathrm{CC}$ with and without $\mathrm{N}$ addition, respectively.

There was a significant $(\mathrm{p}<0.05)$ interaction growing season $x$ cropping sequence for grain yield. In 2009/10, every cropping sequences registered higher grain yield $(\mathrm{p}<0.05)$, which ranged between $3.7 \mathrm{Mg} \mathrm{ha}^{-1}$ and $4.3 \mathrm{Mg} \mathrm{ha}^{-1}$ (Fig. 3). One explanation for this would be the adequate rainfall during the soybean's growing period, which accumulated between the third decade of October (2009) and the second decade of March (2010) (covering the period between CC killing and soybean maturity). It was $71 \mathrm{~mm}$ above the historical median for this period $(499 \mathrm{~mm})$ (Table 1). In addition, there was abundant rainfall between the second decade of February and the first decade of March (Fig. 2), coinciding with the period between R4 (fully developed pod) to R6.5 (fully developed seed) growth stages [28]. This period is proposed as critical for kernel set [38]. In this growing season, grain yield was greater $(\mathrm{p}<0.05)$ in $\mathrm{CC}_{\mathrm{F}} / \mathrm{Sb}$ but lower in $\mathrm{CC} / \mathrm{Sb}$ and $\mathrm{Sb}$ (Fig. 2). On the other hand, in the 2010/11 growing season, rainfall was less favorable for soybean growth. Accumulated rainfall was $66 \mathrm{~mm}$ below the historical median (Table 1). Low rainfall was also recorded during the critical period for kernel set, and, as a consequence, soybean grain yield was affected (Fig. 2). Grain yields did not differ $(\mathrm{p}<0.05)$ between cropping sequences and were in the range of $2.4 \mathrm{Mg} \mathrm{ha}^{-1}$ to $2.7 \mathrm{Mg} \mathrm{ha}^{-1}$ (Fig. 3). This is in line with what was reported by Restovich et al. [20] who determined, in a long-term study, that soybean grain yield was no different with oats as the $\mathrm{CC}$ under different rainfall conditions, from normal to high or exceptionally dry, during soybean growing seasons. During the 2011/12 growing season, accumulated rainfall was $41.2 \mathrm{~mm}$ below the historical median although the rainfall during the critical period for kernel set (which coincided with previous years) was higher than in 2010/2011 (Fig. 2). Soybean yield ranged from 2.7 $\mathrm{Mg} \mathrm{ha}^{-1}$ to $3.1 \mathrm{Mg} \mathrm{ha}^{-1}$, and was higher $(\mathrm{p}<0.05)$ in $\mathrm{CC} / \mathrm{Sb}$ and $\mathrm{CC}_{\mathrm{F}} / \mathrm{Sb}$, than $\mathrm{Sb}$ (Fig. 3).

Under temperate weather conditions in Illinois, with mean soybean grain yield of $2.8 \mathrm{Mg}^{-1}$, Ruffo et al. [19] reported no yield differences with or without a CC. However, in studies performed in Iowa with a range of soybean grain yield similar to those found in our experiment, decreases were reported in shoot biomass and soybean grain yield using rye as the CC $[24,25]$. Despite these results, Pantoja et al. [39], working in four locations in Iowa, reported no significant differences in soybean grain yield following rye, although in their studies the rye shoot biomass production was low ( $<2500 \mathrm{Mg}$ ha).

Results of our study indicate that soybean grain yield did not decrease after the inclusion of a $\mathrm{CC}$ in three growing seasons beyond differences in rainfall. In addition, in 2009/10 when environmental conditions were favorable to achieve high yields and in 2011/12 when, although rainfall was lower, it did not affect the yield much, the sequences with $\mathrm{CC}$ had higher yields than monoculture soybean (except for $\mathrm{CC} / \mathrm{Sb}$ in 2009 that did not differ from $\mathrm{Sb}$ ). This indicates a possible beneficial effect of these management practices on soil productivity, beyond the short period after the implementation. Villamil et al. [17] and Blanco-Canqui et al., [18] reported that the inclusion of $\mathrm{CCs}$ in different cropping sequences increased the organic $\mathrm{C}$ content and improved physical properties that affect soil productivity.

\section{Water Productivity}

Analyzing the three growing seasons, the total rainfall was 2,503 mm (from April 2009 to March 2012), total accumulated shoot biomass by the cropping sequences in this period was higher $(\mathrm{p}<0.05)$ in $\mathrm{CC}_{\mathrm{F}} / \mathrm{Sb}$ followed by $\mathrm{CC} / \mathrm{Sb}$, while $\mathrm{Sb}$ was the lowest (Table 3 ). Therefore, WP was higher $(\mathrm{p}<0.05)$ for sequences with a $\mathrm{CC}$ and even higher when they were $\mathrm{N}$-fertilized, showing WP values that were twice as high as soybean monoculture (Table 3 ). This is consistent with the reports of Caviglia et al. [14] and Caviglia and Andrade [13], who determined a more efficient use of the resources due to the intensification of the production system by increasing the number of crops per year. For the sequences analyzed, the ISI was 2 in $\mathrm{CC}_{\mathrm{F}} / \mathrm{Sb}$ and $\mathrm{CC} / \mathrm{Sb}$ (two crops in one year) while in $\mathrm{Sb}$ it was 1 (one crop in one year). This indicates that increases in the ISI were associated with improvements in WP [13].

\section{CONCLUSIONS}

The results obtained in this experiment showed that the inclusion of a $\mathrm{CC}$ in cropping sequences with soybean predominance improves water productivity and these effects were greater in CCs fertilized with $\mathrm{N}$. On the other hand, $\mathrm{CCs}$ increased the amount of $\mathrm{C}$ provided to the soil through residues, which can improve $\mathrm{C}$ balance. The use of a $\mathrm{CC}$ also takes up substantial amounts of $\mathrm{N}$, which would prevent $\mathrm{N}$ - 
leaching mainly in regions with higher rainfall during the winter period, as is the case in southeast of the Humid Argentine Pampa. This $\mathrm{N}$ immobilized in residues would be recycling back into the soil, and be utilized by following crops in the rotation. Inclusion of a $\mathrm{CC}$ did not restrict soybean grain yield in the three growing seasons when different crop water conditions occurred. In addition, when water availability favored high grain yield, sequences with CCs had higher yields than soybean monoculture. This supports the incorporation of a $\mathrm{CC}$ in crop sequences with a high frequency of soybean in southeast of the Humid Argentine Pampa as a feasible alternative to increase the contribution of $\mathrm{C}$ and $\mathrm{N}$, and to improve the balance of both elements in the soil. It would therefore be useful to evaluate the effects of grass CCs with or without $\mathrm{N}$ fertilization following soybean over the long term, in different environments and production scenarios, on processes that intervene in the dynamic of $\mathrm{C}$ and $\mathrm{N}$ and other parameters that define soil quality. This would allow us a greater understanding around the impact of this management practice on soil productivity and sustainability of the production system.

\section{CONFLICT OF INTEREST}

The authors confirm that this article content has no conflicts of interest.

\section{ACKNOWLEDGEMENTS}

The present work is part of a thesis submitted by Juan Pablo Martínez in partial fulfillment for the requirements for the Postgraduate Program of Universidad Nacional de Mar del Plata (UNMP). This study was carried out thanks to the financial support of the INTA project AERN 295561 and FCA-UNMP AGR 383/12. We are grateful to Adriana Cano for statistical analysis orientation.

\section{REFERENCES}

[1] Satorre EH, Slafer GA. In: Satorre EM, Slafer GA. Eds. Wheat production systems of the Pampas. Wheat. Ecology and Physiology of Yield Determination. New York: The Haworth Press, Inc. 1999; pp. 333-48.

[2] MAGyP [homepage on the Internet]. Ministerio de Agricultura, Ganadería y Pesca. Base de datos sistema integrado de información agropecuaria; 2012. Available from: http:/www.minagri.gob.ar/SAGPyA [updated 2012 May 10]

[3] García FO, Ciampitti IA, Baigorri HE. Manual del cultivo de soja. Buenos Aires. International Plant Nutrition Institute 2009; p. 180.

[4] Alvarez R, Lemcoff JH, Merzari AH. Balance de N en un suelo cultivado con soja. Ciencia del Suelo 1995; 13: 38-40.

[5] Salvagiotti F, Cassman KG, Specht JE, et al. Nitrogen uptake, fixation and response to fertilizer $\mathrm{N}$ in soybeans: a review. Field Crops Res 2008; 108: 1-13.

[6] Collino D, de Luca M, Perticari A, et al. Áreas homogéneas de aporte de nitrógeno por FBN en la región sojera argentina. Actas $24^{\circ}$ Reunion Latinoamericana de Rhizobiologia. La Habana, Cuba. May 4-8, 2009.

[7] Gutiérrez Boem FH, Scheiner JD, Rimski Korsakov H, et al. Late season nitrogen fertilization of soybeans: effects on leaf senescence, yield and environment. Nutr Cycl Agroecosys 2004; 68: 109-15.

[8] Studdert GA, Echeverría HE. Crop rotations and nitrogen fertilization to manage soil organic carbon dynamics. Soil Sci Soc Am J 2000; 64: 1496-503.

[9] Weil RR, Magdoff F. In: Magdoff F, Weil RR. Eds. Significance of soil organic matter to soil quality and health. Soil organic matter in sustainable agriculture. Florida, USA: CRC Press, Boca Ratón, 2004; pp. 1-43.
[10] Lal R. Sequestering carbon in soils of agro-ecosystems. Food Policy $2011 ; 36(1): 33-9$

[11] Sainz RHR, Echeverría HE, Angelini HP. Niveles de carbono orgánico y ph en suelos agrícolas de las regiones Pampeana y Extrapampeana Argentina. Ciencia del Suelo 2011; 29(1): 29-37.

[12] Farahani HJ, Peterson GA, Westfall DG. Dryland cropping intensification: a fundamental solution to efficient use of precipitation. Adv Agron 1998; 64: 197-223.

[13] Caviglia OP, Andrade F. Sustainable intensification of agriculture in the Argentinean Pampas: Capture and use efficiency of environmental resources. Am J Plant Sci Biotech 2010; 3: 1-8.

[14] Caviglia OP, Andrade FH, Sadras VO. Intensification of agriculture in the south-eastern Pampas: I. Capture and efficiency in the use of water and radiation in double-cropped wheat-soybean. Field Crops Res 2004; 87(3): 117-29.

[15] Reeves DW. In: Hatfield JL, Stewart BA. Eds. Cover crops and rotations. Advances in soil science. Crops residue management. FL: CRC Press, Boca Raton 1994; pp. 125-72.

[16] Fageria NK, Baligar VC, Bailey BA. Role of Cover Crops in Improving Soil and Row Crop Productivity. Commun Soil Sci Plan 2005; 36: 2733-57.

[17] Villamil MB, Bollero GA, Darmody RG, Simmons FW, Bullock DG. No-till corn/soybean systems including winter cover crops: effects on soil properties. Soil Sci Soc Am J 2006; 70: 1936-44.

[18] Blanco-Canqui H, Micka MM, Presley DR, et al. Addition of cover crops enhances no-till potential for improving soil physical properties. Soil Sci Soc Am J 2011; 75(4): 1471-82.

[19] Ruffo ML, Bullock DG, Bollero GA. Soybean yield as affected by biomass and nitrogen uptake of cereal rye in winter cover crop rotations. Agron J 2004; 96: 800-5.

[20] Restovich SB, Andriulo AE, Portela SI. Introduction of cover crops in a maize-soybean rotation of the Humid Pampas: effect on nitrogen and water dynamics. Field Crops Res 2012; 128: 62-70.

[21] Kaspar TC, Jaynes DB, Parkin TB, et al. Effectiveness of oat and rye cover crops in reducing nitrate losses in drainage water. Agr Water Manage 2012; 110: 25-33.

[22] Cordone G, Martínez F. El monocultivo de soja y el déficit de nitrógeno. Informaciones Agronómicas del Cono Sur 2004; 24:1-4.

[23] Sainju UM, Singh BP, Whitehead WF. Long-term effects of tillage, cover crops, and nitrogen fertilization on organic carbon and nitrogen concentrations in sandy loam soils in Georgia, USA. Soil Till Res 2002; 63: 167-79.

[24] Singer JW, Kohler KA. Rye cover crop management affects grain yield in a soybean-corn rotation. Available at www.plantmanagementnetwork. Crop Manage 2005; doi:10.1094/CM-2005-0224-02RS.

[25] Westgate LR, Singer JW, Kohler KA. Method and timing of rye control affects soybean development and resource utilization. Agron J 2005; 97: 806-16.

[26] Nielsen DC, Vigil MF. Legume green fallow effect on soil water content at wheat planting and wheat yield. Agron J 2005; 97: $684-$ 9.

[27] Zadoks JC, Chang TT, Konzak CF. A decimal code for growth stages of cereals. Weed Res 1974; 14: 415-21.

[28] Fehr WR, Caviness CE. Stages of soybean development. Iowa St. Univ. 1977; Special Report 80. p. 11.

[29] LECO. homepage on the Internet. Organic application notes; 2010 Available from: http//www.leco.com [updated 2010 Sep 13].

[30] Littell RC, Milliken GA, Stroup WW, et al. SAS ${ }^{\circledR}$ for Mixed Models, second edition. SAS Institute Inc, Cary, NC, USA 2006; p. 814.

[31] Odhiambo JJO, Bomke A. Grass and legume cover crop effects on dry matter and nitrogen accumulation. Agron J 2001; 93: 299-307.

[32] Taboada MA, Micucci FG, Álvarez CR. In: Alvarez R, Rubio G, Álvarez CR, Lavado RS. Eds. Impedancias mecánicas y compactación en sistemas agrícolas. Fertilidad de suelos. Caracterización y manejo en la Región Pampeana. Editorial Facultad de Agronomía, Universidad de Buenos Aires, 2010; pp. 117-54.

[33] Kaspar TC, Singer JW. In: Hatfield JL, Sauer T J. Eds. The Use of Cover Crops to Manage Soil. Soil Management: Building a Stable Base for Agriculture. American Society of Agronomy and Soil Science Society of America, Guilford Road, Madison, USA 2011; 321-37

[34] Paustian K, William J, Persson PJ. Modeling soil organic matter in organic-amended and nitrogen-fertilized long-term plots. Soil Sci Soc Am J 1992; 56: pp. 476-88. 
[35] Clark AJ, Decker AM, Meinsiger JJ, McIntosh MS. Kill date of vetch, rye, and a vetch-rye mixture: I. Cover crops and corn nitrogen. Agron J 1997; 89: 427-34.

[36] Buyanovsky GA, Wagner GH. In: Paul EA, Elliot ET, Cole CV. Eds. Crop residue input to soil organic matter in the Sanborn field. Soil organic matter in temperate ecosystems: Long-term experiments in North America. FL. USA: CRC Press, Boca Raton 1997; pp. 73-83.

[37] Calviño P, Monzon JP. In: Sadras VO, Calderini DF. Eds. Farming systems of Argentina: Yield constraints and risk management. Crop physiology. Netherland: Elsevier 2009; pp. 55-70.
[38] Andrade FH, Aguirrezábal L, Rizzalli RH. In: Andrade F, Sadras V. Eds. Crecimiento y rendimiento comparados. Bases para el manejo del maíz, el girasol y la soja. INTA Balcarce, Facultad de Ciencias Agrarias (UNMP), 2002; pp. 57-96.

[39] Pantoja JL, Sawyer JE, Barker DW. Nitrogen fertilization requirement and corn-soybean productivity in a rye cover cropping system. North Central Extension-Industry Soil Fertility Conference, Des Moines, Iowa. November 17-18, 2010; vol. 26: pp. 88-96.

Received: August 11, 2012

Revised: November 25, 2012

Accepted: December 03, 2012

(C) Martínez et al.; Licensee Bentham Open.

This is an open access article licensed under the terms of the Creative Commons Attribution Non-Commercial License (http://creativecommons.org/licenses/by-nc/3.0/) which permits unrestricted, non-commercial use, distribution and reproduction in any medium, provided the work is properly cited. 